\title{
ДОСЛІДЖЕННЯ ІСТОРИЧНИХ АСПЕКТІВ СТАНОВЛЕННЯ ТА РОЗВИТКУ ВІЙСЬКОВОЇ ФАРМАЦІї В УКРАЇНІ
}

\author{
Я. Б. Лехмак, І. В. Кубарєва, Л. А. Карпенко, В. В. Горбаньов \\ Національний фрармацевтичний університет МОЗ України \\ socpharm@nuph.edu.ua
}

ІНФОРМАЦІЯ

Надійшла до редакції / Received: 12.03.2021

Після доопрацювання / Revised: 24.03.2021

Прийнято до друку / Accepted: 25.03.2021

\section{Ключові слова:}

військова фрармація; військовий провізор; історія;

Україна.

\begin{abstract}
АНОТАЦІЯ
Мета роботи. Здійснити дослідження основних етапів становлення та розвитку військової фрармації (ВФ) в Україні в історичному аспекті.

Матеріали і методи. Методологічну основу дослідження складають принципи історизму, об'єктивності і системності. У роботі використано комплекс загальнонаукових та спеціальних методів: теоретичний, історичний, метод узагальнення, систематизації даних, порівняння, методи вивчення літературно-історичних джерел та аналізу та ін.

Результати й обговорення. Становлення і розвиток ВФ у різних країнах світу значною мірою пов'язані зі створенням армій і веденням бойових дій. На території нашої держави ВФ як самостійна галузь знань ссрормувалася лише у XVII ст., що пов'язано з діяльністю Аптекарського приказу в Російській імперії, одним із основних завдань якого було медичне та лікарське забезпечення армії. Відгалуженню ВФ в окрему дисципліну сприяла діяльність таких видатних вчених, як О. Нелюбін, С. Пржибитек, М. Пирогов та ін. Національний фармацевтичний університет відігравав провідну роль у розвитку ВФ як в освітянському, так і в науковому напрямку за радянських часів та в новітній історії України. На сьогодні освітньо-науковим центром підготовки військових провізорів в Україні $€$ Українська військово-медична академія.

Висновки. У статті проаналізовано історичні аспекти становлення та розвитку ВФ в Україні. Визначено дев'ять основних етапів становлення ВФ, сфрормульовано основні фрактори впливу, характеристики та напрямки її розвитку. За результатами наукового узагальнення історичного досвіду представлено вагомі здобутки вітчизняної ВФ в освітянському, науковому та практичному напрямках, зазначено роль і місце видатних особистостей у формуванні ВФ.
\end{abstract}

Вступ. На сьогодні військова фрармація (ВФ) $€$ окремою галуззю знань, яка історично розвивалася поряд із військовою і традиційною медициною. Вивчення історії ВФ дасть можливість визначити основні тенденції розвитку фрорм і методів медичного та фрармацевтичного забезпечення Збройних сил України, їхні переваги та проблемні питання, залежно від політичних та соціально-економічних фракторів, інших макро- та мікрочинників розвитку суспільства. Становленню ВФ сприяли такі видатні вчені, як О. Нелюбін, С. Пржибитек, Л. Рябих, П. Сазанов, Ю. Трапп, П. Хвещук, А. Хрєнов, Б. Чакчир [1]. Окремі аспекти проблеми вивчали в роботах вітчизняних авторів, а саме М. І. Бадюка 
[2], Є. Бочерикової [3], П. Сироти, О.П. Шматенка та ін. $[4,5]$.

Мета роботи - здійснити дослідження основних етапів становлення та розвитку ВФ в Україні в історичному аспекті.

Матеріали і методи. Методологічну основу дослідження складають принципи історизму, об'єктивності і системності. У роботі використано комплекс загальнонаукових та спеціальних методів: теоретичний, історичний, метод узагальнення, систематизації даних, порівняння, методи вивчення літературно-історичних джерел та аналізу та ін.

Результати й обговорення. Становлення і розвиток ВФ значною мірою пов'язані зі створенням армій і веденням бойових дій. Історичні періоди, впродовж яких відбувалися бойові дії, сприяли активному пошуку ефективних методів і засобів лікування ран і хвороб [6].

Необхідно зазначити, що на території нашої держави ВФ як самостійна галузь знань сорормувалася тільки у XVII ст., її зародження пов'язане з діяльністю Аптекарського приказу у Російській імперії, одним із основних завдань якого було медичне та лікарське забезпечення армії [7]. Але передумови виникнення ВФ можемо зустріти ще за часів стародавнього світу. Так, основні періоди розвитку і становлення ВФ в Україні, їхній зміст та фрактори впливу наведено в таблиці 1.

Таблиця 1

Характерні ознаки основних історичних періодів становлення та розвитку військової фармації в Україні

\begin{tabular}{|c|c|c|c|c|}
\hline № & Періоди & $\begin{array}{l}\text { Хронологічні } \\
\text { межі }\end{array}$ & Фактори впливу & Характерні ознаки та здобутки \\
\hline 1 & 2 & 3 & 4 & 5 \\
\hline I & $\begin{array}{l}\text { Перші } \\
\text { цивілізації } \\
\text { на території } \\
\text { України }\end{array}$ & $\begin{array}{l}\text { VII ст. до н. е. - } \\
\text { перша } \\
\text { половина IX ст. } \\
\text { н. е. }\end{array}$ & $\begin{array}{l}\text { Поява Скіфів на } \\
\text { територіях Північного } \\
\text { Причорномор'я, їхнє } \\
\text { активне військово- } \\
\text { політичне життя }\end{array}$ & $\begin{array}{l}\text { Накопичення та узагальнення емпіричних } \\
\text { знань про природні лікувальні засоби рос- } \\
\text { линного, тваринного і мінерального похо- } \\
\text { дження. } \\
\text { Перші згадки про впровадження школи } \\
\text { лікарської справи та аптек }\end{array}$ \\
\hline II & Київська Русь & $\begin{array}{c}\text { Друга половина } \\
\text { IX - XIV ст. }\end{array}$ & $\begin{array}{l}\text { Становлення держави } \\
\text { Київська Русь. } \\
\text { Прийняття християнства в } \\
\text { Київській Русі. } \\
\text { Значна кількість бойових дій }\end{array}$ & $\begin{array}{l}\text { Активний розвиток народної медицини. } \\
\text { Формування двох нових напрямків } \\
\text { у медицині та фрармації: церковно- } \\
\text { монастирського і світського. } \\
\text { Приорітет розвитку - травматологія }\end{array}$ \\
\hline III & $\begin{array}{l}\text { Українські землі } \\
\text { в складі іно- } \\
\text { земних держав, } \\
\text { доба козацтва }\end{array}$ & XV - XVIII ст. & $\begin{array}{l}\text { Формування Запорізької } \\
\text { Січі, військові походи } \\
\text { козаків }\end{array}$ & $\begin{array}{l}\text { Створення перших польових шпиталів. } \\
\text { Організація перших протиепідемічних } \\
\text { установ та початок упровадження перших } \\
\text { протиепідемічних заходів }\end{array}$ \\
\hline IV & $\begin{array}{l}\text { Україна в скла- } \\
\text { ді Російської та } \\
\text { Австро-Угор- } \\
\text { ської імперій }\end{array}$ & $\begin{array}{c}\text { Кінець XVIII ст. } \\
\text { - початок XX ст. }\end{array}$ & $\begin{array}{l}\text { Відкриття у } 1788 \text { р. } \\
\text { Єлисаветградської } \\
\text { медико-хірургічної школи }\end{array}$ & $\begin{array}{l}\text { Формування основ військової та морської } \\
\text { гігієни. } \\
\text { Активний розвиток аптечної мережі в Україні. } \\
\text { Видання військової фрармакопеї }\end{array}$ \\
\hline V & $\begin{array}{l}\text { Україна } \\
\text { в Першій } \\
\text { світовій війні } \\
\text { та Українській } \\
\text { революції }\end{array}$ & 1914 - 1921 pp. & $\begin{array}{l}\text { Перша світова війна. } \\
\text { Українська революція }\end{array}$ & $\begin{array}{l}\text { Вдосконалення лікувально-евакуаційних } \\
\text { заходів. } \\
\text { Розвиток спеціалізованих видів медичної } \\
\text { допомоги пораненим, санітарно-гігієнічних } \\
\text { та протиепідемічних заходів. } \\
\text { Відродження лікувально-санітарної мережі } \\
\text { в Україні на демократичних засадах, } \\
\text { зорієнтованих на принципи безкоштовності, } \\
\text { загальнодоступності та рівномірності. } \\
\text { Зародження радянської системи ВМ та ВФ }\end{array}$ \\
\hline VI & $\begin{array}{l}\text { Україна у } \\
\text { міжвоєнний } \\
\text { період }\end{array}$ & 1922 - 1939 pp. & $\begin{array}{l}\text { Становлення радянської } \\
\text { моделі медичного й } \\
\text { фармацевтичного } \\
\text { забезпечення }\end{array}$ & $\begin{array}{l}\text { Запровадження нової системи медичного } \\
\text { постачання військ, модернізація медичного } \\
\text { оснащення. } \\
\text { Перехід на систему функціонально- } \\
\text { табельного комплектного оснащення } \\
\text { закладів охорони здоров'я та його } \\
\text { нормування. } \\
\text { Створення автомобільних санітарних взводів. } \\
\text { Головним центром підготовки кадрів стає } \\
\text { Військово-медична академія }\end{array}$ \\
\hline
\end{tabular}

ISSN 2312-0967. Фармацевтичний часопис. 2021. № 2 
Історія фармації

Pharmacy history

Продовження табл. 1

\begin{tabular}{|c|c|c|c|c|}
\hline 1 & 2 & 3 & 4 & 5 \\
\hline VII & $\begin{array}{l}\text { Україна в роки } \\
\text { Другої світової } \\
\text { війни }\end{array}$ & 1939 - 1945 pp. & $\begin{array}{l}\text { Друга світова війна: } \\
\text { втрата значної частини } \\
\text { медичного майна на } \\
\text { початковому етапі } \\
\text { бойових дій }\end{array}$ & $\begin{array}{l}\text { Встановлення нового порядку постачання, } \\
\text { згідно з яким медичне майно поділялося } \\
\text { на майно бойового забезпечення та майно } \\
\text { поточного постачання. } \\
\text { Зосередження військово-медичної } \\
\text { науки на вирішенні таких проблем, як } \\
\text { лікування вогнепальних ран і переломів, } \\
\text { профрілактика лікування шоку, переливання } \\
\text { крові і кровозамінних рідин, відновне } \\
\text { лікування наслідків тяжких поранень }\end{array}$ \\
\hline VIII & $\begin{array}{l}\text { Україна в } \\
\text { післявоєнний } \\
\text { період }\end{array}$ & 1945 - 1991 рp. & $\begin{array}{l}\text { Науково-технічний } \\
\text { прогрес. } \\
\text { Розвиток профрілактичної } \\
\text { медицини. } \\
\text { Розвиток медичної й } \\
\text { фрармацевтичної освіти і } \\
\text { науки }\end{array}$ & $\begin{array}{l}\text { Відновлення й укріплення матеріально- } \\
\text { технічної бази охорони здоров'я: } \\
\text { розширено ліжкову мережу, збільшено } \\
\text { кількість лікарняних та аптечних } \\
\text { закладів, зросла чисельність медичних та } \\
\text { фармацевтичних працівників. } \\
\text { Технічне переозброєння медичної служби. } \\
\text { Розвиток мережі госпіталів, поліклінік, } \\
\text { медичних пунктів, аптек та інших об'єктів }\end{array}$ \\
\hline IX & $\begin{array}{l}\text { Незалежна } \\
\text { Україна }\end{array}$ & I3 1991 p. & $\begin{array}{l}\text { Здобуття Україною } \\
\text { незалежності. } \\
\text { Створення національної } \\
\text { системи військово- } \\
\text { медичної освіти і науки }\end{array}$ & $\begin{array}{l}\text { Ресрормування військово-медичної служби. } \\
\text { Формування управлінських вертикалей: } \\
\text { лікувально-діагностичної, санітарно- } \\
\text { епідеміологічної та вертикалі медичного } \\
\text { постачання ЗС України }\end{array}$ \\
\hline
\end{tabular}

За даними таблиці 1, у VII ст. до н. е. у Північне Причорномор'я зі сходу прийшли іраномовні племена скіфів, які витіснили кіммерійців. Скіфи вели активне військово-політичне життя, тому в цей період активно розвивалася лікувальна справа. Багато інформативних матеріалів 3 історії медицини та фрармації збереглося 3 тих часів. Археологічні розкопки виявили багато медичних інструментів з бронзи, срібла, кістки. Відомо, що скіфські цілителі вміли лікувати рани, опіки, різні хвороби, здійснювати хірургічні втручання, а також застосовували лікувальні засоби як рослинного (горицвіт, солодкий корінь, ревінь, подорожник, цибулю, часник та ін.), так і тваринного (боброву струмінь, жири, мозок) походження. На Культ-Обських вагах, знайдених під час розкопок скіфрського кургану в 1830 році, зображено сцену, де скісрський воїн лікує поранену щелепу іншому воїнові. $€$ згадки, що скіфрські лікарі створили справжню школу лікарської справи [8].

За часів існування скіфів з'явились перші аптеки, де в мініатюрних керамічних посудинах готували різні ліки і парфуми. Залишки однієї з таких аптек знайдені на місці стародавнього грецького міста Ольвії (нині територія біля с. Парутине, що на південь від Миколаєва).

Добре розвинутим було лікознавство в період Київської Русі. Центрами розвитку медицини та фармації доби Київської держави виступали монастирі, зокрема Києво-Печерський, при якому було засновано лікарню, де безкоштовно надавали медичну допомогу, а монахи виготовляли лікарські фрорми у вигляді мазей, відварів, настоїв, пілюль, порошків. Перших носіїв медичних знань, зокрема лікарів-профресіоналів називали, «лечьцями». Окрім володіння медичними знаннями, вони водночас виконували фрункції фармацевтів. Лікарське «зельє» зберігали в спеціальних «погребах» (тогочасних аптеках) [9].

Під час військових дій монастирські лікарні перетворювалися на військові шпиталі.

Внаслідок постійних воєн, в яких перебувала Київська Русь, одним із пріоритетних напрямків тогочасної медицини була травматологія. У військових походах армій періоду XII-XV ст. брали участь світські лікарі. Зазвичай їхньою основною метою було надання допомоги князям та воєначальникам. Рядовим воїнам надавали допомогу спеціалісти ремісники. Це були представники народної медицини, передусім чоловіки. 3 метою заробітку вони супроводжували війська в походах, щоб надавати допомогу хворим і пораненим [10].

Історія України XVI-XVII ст. характеризується запеклою боротьбою українського народу за свою національну самобутність. У цій боротьбі почесну роль відіграли українські козаки. Медицина та фрармація у козаків базувалася на українській народній медицині, проте мала певні відмінності, а саме: практику самолікування та розвинуті заходи щодо запобігання захворюванням. Згодом медичну допомогу козакам стали надавати цирюльники. Вони могли розкривали нариви, перев'язувати рани, виправляти вивихи, робити кровопускання. Іноді козаки у похід брали знахарів, які вміли пускати кров, виривати зуби, виготов-

ISSN 2312-0967. Pharmaceutical review. 2021. № 2 
ляти пластирі для лікування ран, накладати лещата при переломах. Вирушаючи в похід, козаки разом із запасами зброї і харчів обов'язково брали й ліки.

Козаки мали свої шпиталі, перший було засновано в Дубовому лісі на острові між річками Старою та Новою Самарою. Тут були споруджені будинки й церква, оточені захисними ровами. Головний козацький шпиталь - Запорізький Спас - знаходився у Межигір"ї під Києвом. Пізніше головним стає шпиталь у Трахтемирівському Успенському монастирі на Дніпрі нижче Канева.

Описані вище події, без сумніву, можна вважати передумовами зародження ВМ та ВФ на території України.

Започаткуванню ВФ як окремої галузі знань сприяло створення в 1620 році Аптекарського приказу державної медичної адміністративної установи, що відала всіма медичними та аптечними справами в Московській державі, до складу якої були включені землі Лівобережної та Правобережної України впродовж другої половини XVII-XVIII ст. [9]. Найважливішою функцією Аптекарського приказу було забезпечення медичною та лікарською допомогою армії як у мирний час, так і під час військових походів.

На початку XVIII ст. казенних (державних) аптек на Лівобережній Україні було недостатньо і вони не мали можливості забезпечувати лікарськими засобами навіть заможні верстви населення. Зростання потреби в лікарській допомозі змусили уряд провести рефрорми в цій галузі. Згідно з указом Петра I аптечні заклади дозволяли відкривати особам, які мали спеціальну освіту, і використовувати їх для отримання прибутку.

У 1720 р. у Лубнах було відкрито польову аптеку, яка забезпечувала лікарськими засобами та медичними інструментами переважно військові частини. Впродовж XVIII ст. Лубенська аптека була найбільшою аптечною установою України та базою з підготовки аптечних кадрів. У аптечному саду вирощували різноманітні лікарські трави. Аптека мала велику лабораторію де проводилися досліди та експерименти.

У першій половині XVIII ст. активно розвивалася ВФ; створювалися нові похідні аптеки, аптеки в шпиталях, видавалися нові правила про організацію польових аптек. Права і обов'язки лікарів та аптекарів визначав «Генеральний про госпіталі регламент» від 24 грудня 1735 року. Відповідно до цього «Регламенту» штат госпітальної аптеки складався з гезеля (аптекаря), учня і працівника. Аптекар мав виготовляти ліки, приймати медикаменти 3 польової або головної аптеки за замовленням лікаря [12].

Згідно 3 указом Сенату Російської імперії від 10 червня 1755 р. на основі даного «Регламенту» у Києві був заснований військовий шпиталь, який швидко з невеликого (на 50 ліжок) перетворився у великий військовий шпиталь на 800 ліжок у 1792 р. і вже мав понад 1200 ліжок у 1837 р. 31992 р. - це Головний військовий клінічний госпіталь Міністерства оборони України [13].

Оснащення військ медичним майном здійснювали переважно з головних аптек - Петербурзької (верхньої) і Московської (придворної). Ці аптеки виконували функції баз постачання.

Польові аптеки поділялися на нерухомі й рухомі. За штатом на мирний і воєнний час в Російській імперії необхідно було мати п'ять нерухомих аптек, з них в Україні функціонувала Лубенська аптека. До рухомих аптек належали армійські, корпусні та дивізійні аптеки. У воєнний час ці аптеки перетворювалися на базові. Іноді вони вирушали за військом або виділяли похідний підрозділ. Як правило, військові частини забезпечувалися медичним майном у період їхнього зосередження й перед бойовими діями, а під час війни - в міру необхідності. Таку роботу виконувала Лубненська аптека під час російсько-турецьких війн 1737-1739 і 1768-1774 рр. [13].

Медичне майно відпускалося за встановленим табелем-вимогою, де вказували найменування предметів, скільки їх було прийнято й витрачено за місяць, скільки залишилось. До табеля додавався реєстр із більш як 160 найменувань лз і понад 30 назв хірургічних інструментів. Існувало застереження: «Дорогих лекарств избегать, а прочее требовать без излишка».

«Регламентом про утримання польових аптек» 1736 року передбачалося мати в кожній польовій аптеці «добрую и способную рецептурную коляску» та декілька підвод. У полки ліки відпускали безкоштовно. Витрати держави покривалися встановленою системою відрахування грошей із військовослужбовців незалежно від того, зверталися вони за медичною допомогою чи ні.

Під час російсько-турецької війни 1735-1739 років та Семирічної війни з'явилися польові рухомі госпіталі, в складі яких існували польові аптеки [13].

Полкові й дивізійні лазарети забезпечували медичним майном головні рецептурні та морські аптеки. Вони являли собою великі на той час фармацевтичні підприємства. Закупівлю ліків, аптечних товарів та іншого медичного майна здійснювали державні та приватні аптеки як на внутрішньому ринку, так і за кордоном.

Наприкінці XVIII століття 3'явилися перші російські фрармакопеї, які надсилали всім лікарям. Окремою сторінкою в історії ВФ стала поява військових фрармакопей. У 1765 році була видана Фармакопея латинською мовою, яка мала назву - «Военная фрармакопея, содержащая наименования и описания тех лекарств в ящиках хирургов императорских войск, которые 30 необходимо хранить по постановлению Императорской врачебной коллегии» [14]. Це було недержавне видання, яке призначалося для потреб військових шпиталів. Автором її був П. 3. Кондоіді -

ISSN 2312-0967. Фармацевтичний часопис. 2021. № 2 
лейб-медик, директор Медичної канцелярії. Фармакопея містила 191 назву Л3, у тому числі хімічних 38, препаратів рослинного походження - 125 і тваринного - 8. У фрармакопеї наводилися дані про необхідну кількість ЛЗ для укладки і визначені ціни на них. Другий розділ пропонував 47 рецептів складних лікарських фрорм, третій - перелік найменувань близько 50 різних хірургічних інструментів, які входили до обов'язкового набору полкового лікаря-хірурга. Друге видання Російської Фармакопеї з'явилося в 1779 р. за редакцією Х. Пекена; воно охоплювало 214 назв Лз й не містило настанов про лікування та каталогу хірургічних інструментів.

У 1783 р. вийшла перша в історії військово-морського фрлоту фрармакопея військових лікарів Російського фрлоту - «Аптека для Российского фрлота, или роспись всем нужным лекарствам, коих по рангу корабля для шести месяцев вояжа в корабельном ящике иметь должно». Ії̈ автор - доктор медицини О. Г. Бахерахт.

У 1778 р. була видана перша загальнодержавна Фармакопея латинською мовою - «Російська диспенсаторія». Ця книга стала обов'язковою для кожної аптеки, вона містила 770 найменувань лікарських препаратів.

Також у 1866, 1896 і 1913 рр. вийшло ще три видання Військових фрармакопей. Ці фрармакопеї слугували керівництвом у справі виготовлення, зберігання, застосування ліків і містили всі необхідні вказівки щодо перевірки їхньої якості й доцільності призначення. Вони стали настільною книгою для військових лікарів. При складанні військових фрармакопей були внесені значні зміни в номенклатуру реактивів, а також у номенклатуру Лз відповідно до міжнародної домовленості про застосування однакових способів готування сильнодіючих ЛЗ.

Значний внесок у розвиток військової медицини та фрармації XIX ст. зробив Микола Іванович Пирогов (1810-1881 рр.), діяльність якого впродовж багатьох років була пов'язана з Україною [9]. Саме Микола Іванович Пирогов науково обґрунтував використання ефрірного наркозу. Разом з фрізіологом О. Філомофітським у дослідах на тваринах були описані властивості еріру 3 наступною клінічною перевіркою. В 1847 р. М. І. Пирогов випробував у бойових умовах ефрірний наркоз. Пізніше М. І. Пирогов брав участь у Кримській кампанії. Він особисто виконав близько 10 тис. ампутацій та розтинів. Під час проживання 3 1866 р. у садибі під Вінницею він займався вирощуванням рослин, необхідних для приготування ліків. На території садиби було побудовано невеличкий будиночок, де розміщувалась аптека.

Під час Першої світової війни Україна опинилась в епіцентрі бойових дій, більшість районів Галичини були повністю зруйновані, майно втрачено. Постачання ЛЗ із країн Європи різко скоротилося, виник дефіцит ліків, їхня вартість стрімко зросла. Виникла необхідність екстреного створення заводів із виробництва ліків [15].

Період 1914-1920 р. був надзвичайно складним в історії України, яка перетворилася на арену боротьби за владу між різними політичними силами.

Діяльність урядів Центральної Ради (Української Народної Республіки) (березень 1917 - квітень 1918 рр.), Гетьманщини (29 квітня - 14 грудня 1918 р.) і Директорії УНР (грудень 1918 - 1920 рр.) у галузі медицини та фрармації була спрямована на відродження лікувально-санаторної мережі в Україні, зорієнтованих на принципи безоплатності, загальнодоступності та рівномірності.

Заходи Центральної Ради щодо відбудови системи охорони здоров'я в Україні передбачали: створення центрального апарату управління охороною здоров'я та його органів на місцях; боротьбу з інфекційними захворюваннями; організацію інституту вдосконалення лікарів; збереження мережі лікувальних закладів і медичного персоналу та ін.

У листопаді 1917 р. після проголошення Центральною Радою Української Народної Республіки при Генеральному Секретаріаті було створено Головну медико-санітарну управу для управління справою охорони здоров'я в Україні, яку очолив професор Б. Матюшенко.

Роки війни та громадянської смути призвели Україну до стану руїн. У цей час фрармацевтичне забезпечення населення країни було вкрай незадовільне. Весь персонал аптек було мобілізовано, запаси л3, предметів догляду за хворими та медичного інструментарію було передано військовим лікувальним закладам. Скоротилася кількість аптек при повній відсутності джерел поповнення ліків. Управління фрармацевтичною справою було передано фрармацевтичним підрозділам медико-санітарних відділів місцевих Рад. Останніми були розроблені положення та інструкції про порядок відпуску ліків та контролю за роботою аптек, переліки дозволених ЛЗ. ЛЗ децентралізовано розповсюджували та відпускали безкоштовно.

Після встановлення Радянської влади створювалась нова система медичного постачання військ, здійснювалась модернізація медичного оснащення. Відбувався перехід на систему фрункціонально-табельного комплектного оснащення та його нормування. Приймалась на забезпечення автосанітарна техніка. У 1923 р. були розроблені й затверджені описи комплектів перев'язувальних засобів, а в 1926 р. введені тимчасові каталоги предметів медичного постачання на мирний та воєнний час.

Другу світову війну 1939-1945 рр. медична служба Червоної Армії зустріла вже досить оснащеною медичним майном, яке відповідало тогочасному рівню досягнень науки й практики. Однак через допущені помилки на початку війни, серйозні недоліки в ешелонуванні запасів значна частина медичного майна була втрачена.

ISSN 2312-0967. Pharmaceutical review. 2021. № 2 
Війна вимагала внесення серйозних коректив в організаційні принципи медичного постачання. Було встановлено новий порядок постачання, згідно 3 яким медичне майно поділялося на майно бойового забезпечення та майно поточного постачання. Майно бойового забезпечення містило стислий перелік предметів, необхідних у великій кількості на час бойових дій. Воно відпускалось позачергово за фрактичною потребою.

Забезпечення медичним майном здійснювалось за схемою центр - фронт - армія - дивізія - полк.

Досвід Другої світової війни засвідчив, що успіх медичного постачання залежить не тільки від наявності запасів майна, але й від оперативності його постачання за призначенням, правильного маневрування силами та засобами.

У лікувальній практиці широко застосовувались фрізіотерапевтичні методи з використанням грязей, торфу, піску, картоплі, насіння льону, а також масаж (самомасаж), розтирання, компреси тощо [15]. Поступово з'являвся досвід, удосконалювались система постачання й методи надання пораненим і хворим медичної допомоги в умовах партизанських загонів та з'єднань.

Медичні працівники навчились самостійно виготовляли перев'язувальні засоби (використовуючи полотно, віконні марлеві фріранки), стерилізували їх і використовували для перев'язування. Для зупинки кровотеч використовували джгути, тканину. Налагодили виготовлення шин для іммобілізації переломів, використовуючи для цього фанеру, дошки, кору дуба та осики. 3 парашутної тканини шили білизну, санітарні сумки, використовували їх як операційні палатки [14].

Розчини новокаїну, глюкози, фрізіологічний розчин натрію хлориду готували на дощовій воді, в якій попередньо розчиняли питну соду та марганцевокислий калій. Фільтрували крізь марлю з ватою та здрібненим порошком активованого вугілля. Приготовані розчини стерилізували на звичайному водному обігрівачі.

Виключно важливу роль у розвитку та становленні фрармацевтичної науки взагалі та зокрема ВФ відіграли такі видатні вчені, як О. П. Нелюбін, Ю. К. Трапп, С. А. Пржибитек та ін.

Окремо, на нашу думку, слід згадати події, пов'язані зі становленням та розвитком військової фрармацевтичної освіти в Україні.

Так, першим осередком фармацевтичної освіти в Московській державі став Аптекарський приказ. При ньому в 1654 р. була відкрита аптекарська школа 3 підготовки лікарів, підлікарів, лікарських і аптекарських учнів, які надавали медичну допомогу під час військових дій та епідемій холери й чуми [16].

Початок створенню військових кафедр для підготовки спеціалістів медичної служби для військ було покладено постановою ЦВК та РНК від 20 серпня
1926 року, відповідно до якої у вузах і технікумах було введено вищу допризивну військову підготовку студентів (ВДВП) і створено так звані військові кабінети. Успішне освоєння курсу ВДВП прирівнювалося до закінчення дивізійних (полкових) шкіл відповідного роду військ, які готували молодший командно-керівний склад.

У 1936 р. у Харківському фрармацевтичному інституті (ХФІ) створено кафедру військово-санітарної підготовки, на якій студенти вивчали організацію медичного забезпечення Червоної Армії [17]. Завідуючим кафедрою у 1936-1938 рр. та у 1946-1949 рр. був дивізійний ветеринарний лікар, полковник Л. Е. Шкловський. Кафедра здійснювала керівництво роботою гуртків підготовки студентів до складання заліків: «Готовий до санітарної оборони», «Готовий до протихімічної оборони», «Готовий до праці і оборони», «Шофер аматор».

У січні 1960 р. згідно з установою Ради Міністрі СРСР кафедра військово-санітарної підготовки у ХФІ, як і в окремих інших цивільних вузах, була скорочена.

З 1952 до 1958 р. одночасно з кафедрою військово-санітарної підготовки існував і військово-фрармацевтичний факультет, який був створений за постановою Ради Міністрів СРСР. Першим начальником фракультету був призначений полковник медичної служби Ф. М. Коломієць, а начальником курсу - полковник медичної служби В. Г. Чорнобровий.

У 1957 р. вперше в історії України 89 слухачів фракультету отримали звання військових провізорів (до цього часу лише у Франції та США випускали таких спеціалістів). У 1958 р. відбувся другий і останній випуск військових провізорів, того ж року військово-медичні фракультети були розформовані.

У період з 1970 до 1990 р. військових провізорів для ЗС СРСР готували у Ленінградській військовомедичній академії імені С. М. Кірова та на військовомедичному фракультеті в Томському медичному інституті, де навчалось багато випускників ХФІ. Тоді як провізори, які проходили навчання на кафедрах військової підготовки фармацевтичних фракультетів медичних ЗВО, зокрема у Львові та Запоріжжі, отримували звання офріцерів запасу.

З 1 березня 1997 р. за наказом ректора Української фрармацевтичної академії профресора В. П. Черних була створена кафедра екстремальної і військової медицини. Головними завданнями кафедри були: забезпечення державних потреб у висококваліфрікованих фрахівцях для створення єдиної загальнодержавної системи медичного забезпечення цивільного населення і військовослужбовців на випадок надзвичайних ситуацій; навчання студентів за програмою підготовки офріцерів медичної служби запасу, удосконалення знань інтернів та слухачів з актуальних питань організації медичного забезпечення 3С України відповідно до військово-облікової спеціальності

ISSN 2312-0967. Фармацевтичний часопис. 2021. № 2 
«Фармація»; задоволення потреб студентів, інтернів, слухачів у набутті знань, умінь і навичок, необхідних для належного виконання ними військового обов'язку в запасі в мирний час, обов'язків військової служби у воєнний час, а також для майбутньої профресійної діяльності.

Для студентів, які навчались на кафедрі за програмою офріцера медичної служби запасу, викладали, зокрема, такі навчальні дисципліни: загальновійськова підготовка; загальна тактика; медицина катастроф; військова токсикологія; радіологія та медичний захист; організація медичного забезпечення військ; організація забезпечення військ медичним майном. Завершальним етапом навчання студентів за програмою офріцера медичної служби був навчальний збір, який проводився на базі військової частини. Наприкінці збору студенти приймали Військову присягу. Студенти, які освоїли повному обсязі навчальну програму та успішно склали Комплексний випускний іспит, атестувались до офріцерського складу медичної служби запасу. У 2011 р. кафедра екстремальної і військової медицини НФаУ була ліквідована.

У 90-ті роки підготовка військових провізорів здійснювалась також на кафедрі ВФ, яка була створена у 1995 р. у структурі Української військово-медичної академії (УВМА) [18].

Значний внесок у розвиток ВФ в Україні зробили профресор кафедри ВФ УВМА П. Сирота і профресор кафедри організації та економіки орармації, декан медико-профрілактичного та фрармацевтичного фра- культету НМАПО імені П. Л. Шупика В. Трохимчук [7, 18].

На сьогодні Українська військово-медична академія - це вищий військово-медичний навчальний, науковий і лікувальний заклад Міністерства оборони України, який забезпечує підготовку висококвалісрікованих кадрів за напрямами ВМ та ВФ.

Таким чином, вітчизняна ВФ має видатну історію й бере свій початок від перших скіфських племен на території сучасної України. Історичні події значною мірою вплинули на становлення та розвиток вітчизняної ВФ як потужної науково-практичної та освітньої галузі.

Висновки. 1. У статті проаналізовано історичні аспекти становлення та розвитку ВФ в Україні. Визначено дев'ять основних етапів становлення ВФ, сформульовано основні фрактори впливу, характеристики та напрямки її розвитку.

2. За результатами наукового узагальнення історичного досвіду представлено вагомі здобутки вітчизняної ВФ в освітянському, науковому та практичному напрямках, зазначено роль і місце видатних особистостей у формуванні ВФ.

3. Перспективним напрямком подальших досліджень вважаємо обґрунтування організаційно-економічних заходів щодо удосконалення сучасної ВФ в Україні з огляду на зарубіжний досвід та фрактори впливу сьогодення.

Конфлікт інтересів: відсутній.

Conflicts of interest: authors have no conflict of interest to declare.

\title{
STUDY OF HISTORICAL ASPECTS OF FORMATION AND DEVELOPMENT OF MILITARY PHARMACY IN UKRAINE
}

\section{Ya. B. Lekhmak, I. V. Kubarieva, L. A. Karpenko, V. V. Horbanyov}

\author{
National University of Pharmacy of the Ministry of Health of Ukraine, Kharkiv
}

socpharm@nuph.edu.ua

The aim of the work. To study the main stages of the formation and development of military pharmacy (MPh) in Ukraine historically.

Materials and Methods. The research methodology is based on the principles of historicism, objectivity and consistency. In the work a complex of general scientific and special methods: theoretical, historical, method of generalization, systematization of data, comparison, methods of studying literary and historical sources and analysis, etc. is used.

Results and Discussion. The formation and development of the MPh in different world countries is largely associated with the creation of armies and the conduct of hostilities. On the territory of our state, the MPh as an independent branch of knowledge was formed only in the 17th century, which is associated with the activities of the Pharmaceutical Order in the Russian Empire, one of the main tasks of which was the provision of medical and pharmaceutical supplies to the army. The branch of the MPh into a separate discipline was facilitated by the activities of such outstanding scientists as $\mathrm{O}$. Nelyubin, S. Przhibitek, M. Pyrohov, etc. The National University of Pharmacy played a leading role in the development of the MPh both in educational and scientific areas, in Soviet times and in the modern history of Ukraine. Today, the Ukrainian Military Medical Academy is the educational and scientific center for training military pharmacists in Ukraine.

Conclusions. The article analyzes the historical aspects of the formation and development of the MPh in Ukraine. The nine main stages of the formation of the MPh are determined, the main factors of influence, characteristics and directions of its development are formulated. Based on the results of the scientific generalization of historical experience, significant

ISSN 2312-0967. Pharmaceutical review. 2021. № 2 
Історія фармації

Pharmacy history

achievements of the domestic MPh in educational, scientific and practical areas are presented, the role and place of outstanding personalities in the formation of the MPh are noted.

Key words: military pharmacy; military pharmacist; history; Ukraine.

\title{
ИССЛЕДОВАНИЕ ИСТОРИЧЕСКИХ АСПЕКТОВ СТАНОВЛЕНИЯ И РАЗВИТИЯ ВОЕННОЙ ФАРМАЦИИ В УКРАИНЕ
}

\author{
Я. Б. Лехмак, И. В. Кубарева, Л. А. Карпенко, В. В. Горбанев \\ Национальный фрармацевтический университет мОз Украины, Харьков \\ socpharm@nuph.edu.ua
}

Цель работы. Провести исследование основных этапов становления и развития военной фармации (ВФ) в Украине в историческом аспекте.

Материалы и методы. Методологическую основу исследования составляют принципы историзма, объективности и системности. В работе использован комплекс общенаучных и специальных методов: теоретический, исторический, метод обобщения, систематизации данных, сравнение, методы изучения литературно-исторических источников и анализа и др.

Результаты и обсуждение. Становление и развитие ВФ в разных странах мира в значительной степени связано с созданием армий и ведением боевых действий. На территории нашего государства ВФ как самостоятельная отрасль знаний сфрормировалась только в XVII в., что связано с деятельностью Аптекарского приказа в Российской империи, одной из основных задач которого было медицинское и лекарственное обеспечение армии. Ответвлению ВФ в отдельную дисциплину способствовала деятельность таких выдающихся ученых, как А. Нелюбин, С. Пржибитек, Н. Пирогов и др. Национальный фрармацевтический университет играл главную роль в развитии ВФ как в образовательном, так и в научном направлениях в советское время и в новейшей истории Украины. На сегодня образовательно-научным центром подготовки военных провизоров в Украине является Украинская военномедицинская академия.

Выводы. В статье проанализированы исторические аспекты становления и развития ВФ в Украине. Определены девять основных этапов становления ВФ, сфрормулированы основные фракторы влияния, характеристики и направления ее развития. По результатам научного обобщения исторического опыта представлены весомые достижения отечественной ВФ в образовательном, научном и практическом направлениях, отмечены роль и место выдающихся личностей в формировании ВФ.

Ключевые слова: военная фрармация; военный провизор; история; Украина.

\section{Список бібліографічних посилань}

1. Трохимчук В. В., Гульпа В. С. Військова фрармація. URL: http://esu.com.ua/search_articles.php?id=34469.

2. Історія військової медицини / за ред. проф. М. І. Бадюка. К. : «МП Леся», 2016. 314 с.

3. Бочерикова $€$. Військовий провізор у сучасній формації. Щотижневик АПТЕКА. 2016. № 12. С. 10.

4. Сучасні підходи до нормування медичного майна для потреб ЗС України та інших військових формувань: навч. посіб. / Шматенко О. П., Трохимчук В. В., Руденко В. В., Сирота П. С. К. : ПП «Блудчий М. І.». 2012. 112 с.

5. Досвід з оснащення військових аптек для отримання інфузійних розчинів у польових умовах / Шматенко О. П., Хомутецька Н. І., Голуб А. Г., Руденко В. В. Військ. медицина України. 2018. Т.18, № 2. С. 62-6.

6. Gali Halevi. Military medicine and its impact on civilian life. Research Trends. 2013. Is. 34. URL: https:// www.researchtrends.com/issue-34-september-2013/ military-medicine-and-its-impact-on-civilian-life/.
7. Екстремальна і військова фрармація / Трохимчук В. В., Сирота П. С., Гринчук І. Г., Лотоцький В. В. Тернопіль : Укрмедкнига, 2003. 332 с.

8. Бліхар $€$. Про медицину скіфрів. URL: http:// elartu.tntu.edu.ua/bitstream/123456789/13878/2/ ProcNTShTB_2004v1_Blikhar_le-Pro_medytsynu_ skifiv_172-176.pdf.

9. Історія медицини та фрармації: навч. посіб. для студ. вищ. фрармац. навч. закл. та фрармац. фр-тів ВНЗ МОЗ України / Котвіцька А. А. та ін. Х. : НФаУ : Золоті сторінки. 2016. 168 с.

10. Голяченко О. М., Ганіткевич О. М. Історія медицини : посіб. Тернопіль : ТДМУ. 2016. 326 с.

11. Сятиня М. Л. Історія фрармації. Львів. 2002. 660 с.

12. Бухтіярова І. Г., Кирилович П. М. Історичний розвиток сорери надання медичної допомоги в Україні. URL: http://lsej.org.ua/1_2020/36.pdf.

13. Організація медичного забезпечення військ : підруч. для студ. вищ. мед. (фармац.) навч. закл. України

ISSN 2312-0967. Фармацевтичний часопис. 2021. № 2 
III-IV рівн. акред. / за ред. М. І. Бадюка ; Укр. військ.мед. акад. МО України. Вид. 2-ге, переробл. і допов. Київ : МП «Леся», 2017. 491 с.

14. Волох Д. С., Сятиня М. Л. Науково-методичні основи викладання історії створення фрармакопеї студентам фрармацевтичного фракультету. Фармац. журн. 2014. № 2. С. 27-33.

15. Богатирьова Р. В., Спіженко Ю. П., Черних В. П. Історія фрармації України. Х. : Прапор : Вид-во УкрФА, 1999. 799 с.

16. Котвіцька А. А., Кубарєва І. В., Горбаньов В. В. Дослідження характерних ознак становлення та розвитку фрармацевтичної освіти в Україні. Сучасна фрармація: історія, реалії та перспективи розвитку: матеріали науково-практичної конференції з міжнародною участю, присвяченої 20-й річниці заснування Дня срармацевтичного працівника України. Харків, 19-20 вересня 2019 р. Харків : НФаУ, 2019. Т. 2. С. 449-51.

17. Історія Національного фрармацевтичного університету люди, події, фракти / за ред. В. П. Черних. Х. : Вид-во НФаУ : Золоті сторінки, 2005. 624 с.

18. Сирота П. С., Трохимчук В. В., Хомутецька Н. І. Кафредра військової фрармації. Військ. медицина України. 2002. Т. 2. № 4. С. 25-30.

\section{References}

1. Trokhymchuk VV, Gulpa VS. Military pharmacy. Available from: http://esu.com.ua/search_articles. php?id=34469. Ukrainian.

2. History of military medicine. [Історія військової медицини] Kyiv; 2016. Ukrainian.

3. Bocherikova E. [Military pharmacist in modern pharmacy]. Shchotyzhnevyk APTEKA. 2016;12: 10. Ukrainian.

4. Shmatenko OP, Trokhimchuk VV, Rudenko VV, Syrota PS. Modern approaches to the rationing of medical property for the needs of the Armed Forces of Ukraine and other military formations. Navch. posibnyk. [Сучасні підходи до нормування медичного майна для потреб ЗС України та інших військових формувань. Навч. посібник.] Kуiv; 2012. Ukrainian.

5. Shmatenko OP, Khomutetskaya NI, Golub AG, Rudenko VV. Experience in equipping military pharmacies to obtain infusion solutions in the field. Viisk. medytsyna Ukrainy. 2018;18(2): 62-6. Ukrainian.

6. Gali Halevi. Military medicine and its impact on civilian life. Research Trends. 2013. Is. 34. Available from: https://www.researchtrends.com/issue-34-september-2013/military-medicine-and-its-impact-on-civilianlife/. Ukrainian.

7. Trokhymchuk VV, Syrota PS, Grinchuk IG, Lototsky VV. Extreme and military pharmacy. [Екстремальна і військова фрармація] Kyiv: Ukrmedknyha; 2003. Ukrainian.

8. Blikhar E. [About Scythian medicine]. Available from: http://elartu.tntu.edu.ua/bitstream/123456789/13878/2/ProcNTShTB_2004v1_ Blikhar_le-Pro_medytsynu_skifiv_172-176.pdf.

9. Kotvitska AA, Horbanyov VV, Havrish NB, Volkova AV, Surikov OO. History of medicine and pharmacy: textbook. [Історія медицини та фрармації: навч. посіб. для студентів вищ.фрармац. навч. закл. та фрармац. фр-тів ВН3 МОЗ України] Kharkiv: NFaU : Zoloti storinky; 2016. Ukrainian.

10. Golyachenko OM, Ganitkevych OM History of medicine: textbook. [Історія медицини: посібник] Ternopil:

Ternopil State Medical University; 2016. Ukrainian.

11. Syatinya ML. History of pharmacy: textbook. [Історія фрармації] Lviv; 2002. Ukrainian.

12. Bukhtiyarova IG, Kirillovych PM Historical development of medical care in Ukraine. Available from: http://lsej. org.ua/1_2020/36.pdf. Ukrainian.

13. Organization of medical support of troops: a textbook for students of higher medical (pharmaceutical) educational institutions of Ukraine III-IV levels of accreditation. [Організація медичного забезпечення військ : підручник для студентів вищих медичних (фармацевтичних) навчальних закладів України IIIIV рівнів акредитації] Kyiv; 2017. Ukrainian.

14. Volokh DS, Syatinya ML [Scientific and methodological bases of teaching the history of pharmacopoeia to students of the Pharmacy Faculty]. Farmats. zhurn. 2014; 2: 27-33. Ukrainian.

15. Bogatyreva RV, Spizhenko YuP, Chernykh VP History of pharmacy of Ukraine. [Історія фрармації України] Kharkiv: Prapor: Vid-vo UkrFA; 1999. Ukrainian.

16. Kotvitska AA, Kubarieva IV, Horbanyov VV. Research of characteristic signs of formation and development of pharmaceutical education in Ukraine. [Дослідження характерних ознак становлення та розвитку фрармацевтичної освіти в Україні] In: Modern pharmacy: history, realities and prospects of development: materials of the scientific-practical conference with international participation, dedicated to the 20th anniversary of the founding of the Day of the pharmaceutical worker of Ukraine 2019 Sept 19-20; Kharkiv (Ukraine): NUPh; 2019. Ukrainian.

17. Chernykh VP. Ed. History of the National University of Pharmacy people, events, facts. [Історія Національного фрармацевтичного університету люди, події, фракти] Kharkiv: Vyd-vo NFaU: Zoloti storinky; 2005. Ukrainian.

18. Syrota PS, Trokhymchuk VV, Khomutets'ka NI. [Department of Military Pharmacy]. Viisk. medytsyna Ukrainy. 2002;2(4): 25-30. Ukrainian. 
Історія фармації

Pharmacy history

\section{Відомості про авторів}

Лехмак Я. Б. - асп. кафедри соціальної фрармації, Національний фрармацевтичний університет Міністерства охорони здоров'я України, Харків, Україна. E-mail: socpharm@nuph.edu.ua.

Кубарєва І. В. - канд. фрармац. наук, доцент кафедри соціальної фрармації, Національний фрармацевтичний університет Міністерства охорони здоров'я України, Харків, Україна. E-mail: inna.kubarieva@gmail.com, ORCID 00000001-6617-2575.

Карпенко Л. А. - канд. фрармац. наук, доцент кафедри соціальної фрармації, Національний фрармацевтичний університет Міністерства охорони здоров'я України, Харків, Україна. E-mail: karpenko_2015@ukr.net, ORCID 00000003-0473-1102.

Горбаньов В. В. - канд. істор. наук, асистент кафедри соціальної фрармації, Національний фрармацевтичний університет Міністерства охорони здоров'я України, Харків, Україна. E-mail: vgorbaniov@gmail.com, ORCID 00000003-2884-2974.

\section{Information about the authors}

Lekhmak Ya. B. - PhD-student, Department of Social Pharmacy, National University of Pharmacy Ministry of Health of Ukraine, Kharkiv, Ukraine. E-mail: socpharm@nuph.edu.ua.

Kubarieva I. V. - PhD (Pharmacy), Associate Professor of the Department of Social Pharmacy, National University of Pharmacy of the Ministry of Health of Ukraine, Kharkiv, Ukraine, e-mail: inna.kubarieva@gmail.com, ORCID 0000-00016617-2575.

Karpenko L. A. - PhD (Pharmacy), Associate Professor of the Department of Social Pharmacy, National University of Pharmacy of the Ministry of Health of Ukraine, Kharkiv, Ukraine, e-mail: karpenko_2015@ukr.net, ORCID 0000-00030473-1102.

Horbanyov V.V. - PhD (History), Assistant of the Department of Social Pharmacy, National University of Pharmacy of the Ministry of Health of Ukraine, Kharkiv, Ukraine, e-mail: vgorbaniov@gmail.com, ORCID 0000-0003-2884-2974. 